\title{
Including Entrepreneurship in the Computer Science Graduate Program
}

\author{
Francisco J. Mata \\ Programa de Posgrado en Computación e Informática \\ Universidad de Costa Rica \\ San José, Costa Rica \\ francisco@mata.name \\ Claudio Pinto \\ Programa de Posgrado en Computación e Informática \\ Universidad de Costa Rica \\ Fair Play Labs \\ San José, Costa Rica \\ claudio.pinto@fairplaylabs.com
}

\begin{abstract}
This article discusses the design of the course Entrepreneurship in Information Technology, taught in the Graduate Program in Computer Sciences and Informatics of the Universidad de Costa Rica during the II semester of 2006. It presents the motives behind this course and the epistemological and pedagogical aspects taken into consideration in its design. The course objectives, its themes and topics, the schedule and the evaluation for the students are also presented. Finally, the paper provides an assessment of the course, including recommendations for its improvement.
\end{abstract}

Keywords: Entrepreneurship, Information Technology, Computer Science Program, Graduate Course

\section{Introduction}

Information technology (IT) has contributed in recent years to the creation of new enterprises in Costa Rica, which have had a significant impact to the country's economy. In the year 2005, 289 IT companies were identified in Costa Rica, which contributed more than US\$2 billion to the GDP, 90\% corresponding to exports and employed around 25,000 persons [7].

Two groups can be clearly identified within these companies. The first group is composed by approximately 60 enterprises, mainly subsidiaries of multinational corporations, which are primarily dedicated to producing electronic components, such as Intel, and to offering IT-enabled services, for example Sykes, Hewlett-Packard, IBM Global Services, Procter \& Gamble and Western Union. The second group, on the other hand, is formed by around 230 small and medium enterprises (SMEs), the majority created by Costa Rican professionals and oriented towards software development and maintenance. Companies in this second group contributed US\$248 million to the GDP, $45 \%$ of that amount were exports, and provided work for approximately 7,000 employees in the year 2005.

Although the economic importance of the IT SMEs in the second group described could be attenuated with regards to the first one, it is important to highlight that the majority of the added-value of these companies remains in the country. Furthermore, it is important to emphasize the contribution of the indigenous companies in the IT assimilation and adaption in the country, as well as in the generation of new technology and intellectual property which could later be the foundation for developing new products and services at the global level. Such contributions are not theoretical, since they are examples of IT indigenous companies in the country which have reached already a presence in more than 50 countries around the world [12].

Therefore, the creation of new IT companies by Costa Rican entrepreneurs is vital for the economic and technological development of the country. However, IT professionals have little knowledge in matters related to entrepreneurship and management of SMEs, which in the end limits the number of new companies created. This situation has awakened the interest in both the public and the private sectors to find effective mechanisms to support 
the inception and growth of IT companies in the country. A good example of such mechanisms is the LINK Program, funded by the Inter-American Bank. ${ }^{1}$

Taking into consideration the importance that education can have within these efforts, the authors of this article took the initiative to design a graduate course with the objective of teaching to computer science graduate students relevant aspects of entrepreneurship and their application to the IT industry.

Entrepreneurship is actually a topic of great importance worldwide. Many universities worldwide, for example the Massachusetts Institute of Technology (MIT) [http://entrepreneurship.mit.edu/entre courses.php], Harvard University [http://www.hbs.edu/entrepreneurship/], the Entrepreneurship Development Institute of India [http://www.ediindia.org/], the National University of Singapore [http://www.nus.edu.sg/nec/] and INCAE Business School (INCAE) [http://www.incae.ac.cr/ES/ centro_empresarialismo/], currently offer courses on this topic. However, the majority of such courses are taught by business schools and have little relation to IT or cover only general technology management. Consequently, the development of an entrepreneurship course within the computer science program raises a series of epistemological and pedagogical challenges. These challenges had to be confronted to offer the course Entrepreneurship in Information Technology, as part of the Graduate Program in Computer Science and Informatics of the Universidad de Costa Rica in the II semester (August to December) of 2006.

This paper presents the curricular considerations taken into account in the design of the previously-mentioned course and provides recommendations which may be used to develop similar courses. Section 2 discusses the epistemological and section 3 the epistemological aspects considered for this course. The objectives and main themes and topics for the course are presented in section 4. Section 5 describes the course schedule and evaluation for the students. Finally, section 6 provides and assessment of the course and recommendations for its improvement.

\section{Epistemological aspects of the course}

According to Zimmerer and Scarborough, "[a]n entrepreneur is one who creates a new business in the face of risk and uncertainty for the purpose of achieving profit and growth by identifying significant opportunities and assembling the necessary resources to capitalize on them" [41, p.3]. Based on this definition, two classes of epistemological aspects are proposed for an IT entrepreneurship course: the first one related to general aspects of entrepreneurship and the second about entrepreneurship aspects applied to IT.

\subsection{General aspects of entrepreneurship}

The following general concepts about entrepreneurship were deemed important for designing this course:

- Importance of entrepreneurship and the role of SMEs in the world economy;

- Characteristics of an entrepreneur and his/her role in creating new companies;

- Benefits and disadvantages of entrepreneurship;

- Importance of a business plan for entrepreneurship.

An Internet search showed that the book Essentials of Entrepreneurship and Small Business Management, written by Zimmerer and Scarborough [41], is one of the most commonly used in entrepreneurship courses in US universities. An analysis of this book revealed that it presents in a simple manner general concepts about entrepreneurship. This is very useful for students with few training in business administration, as it is the case with computer science majors. Furthermore, it describes in a fairly detailed way a methodology to write a business plan. Another advantage of this book is the mini-cases provided for analysis by the students under the heading "You Be The Consultant ..." Such cases were very useful as homework, as well as for class discussions.

The information provided by this book was complemented by the following bibliographic resources:

- Crossing the Chasm [25]: this book presents matters related to the technology adoption cycle. According to Moore, its author, users of new technologies can be classified as: innovators, early adopters, early majority, late majority and laggards. Based on this typology, Moore discusses the "chasm" that exists in technology adoption primarily between innovators, who are visionaries, and early adopters, who are pragmatists. These two groups have different technology expectations. Moore explores these differences and suggest ways to successfully cross the chasm, based on target marketing, positioning, distribution and

\footnotetext{
${ }^{1}$ For more details see http://www.teclink.org
} 
pricing. In this way, a firm might be successful to create a "bandwagon effect", building momentum for its product and assisting it to become a de facto standard [40].

- It's a Flat World, After All [13]: This article written by Friedman, first published by The New York Times and later expanded into a book [14], describes how globalization has reduced time and space making it possible to firms to render certain functions to others, even in other countries and regions of the world, paving the way to "global outsourcing". This phenomenon has opened countless possibilities to create new companies in developing countries, many of them related to IT.

- How to Write a Great Business Plan [32]: This article by Sahlman was published in Harvard Business Review. In a very amenable manner, this work provides recommendations and suggestions to write an effective business plan.

\subsection{Entrepreneurship aspects related to IT}

The second group of epistemological aspects considered in the design of the course relates to entrepreneurship and IT. This group was included primarily with the purpose of presenting opportunities and threats in creating new IT companies, and in turn, was divided into three major themes:

- Entrepreneurship and software development;

- Entrepreneurship and IT-enabled services;

- Critical aspects for IT entrepreneurship in Costa Rica.

Unlike the first group of epistemological aspects already discussed, it was not possible to find a textbook covering the themes identified for this second group. Nevertheless, the following articles, available on Internet and dealing with entrepreneurship and software development in key countries, were found useful:

- In the footsteps of the Silicon Valley? Indian and Irish Software in the International Division of Labor [2];

- $\quad$ The Indian Software Industry [3];

- India's Information Technology Sector: What Contribution to Broader Economic Sector [34]:

- China's Software Industry and its Implications for India [37].

After teaching the course, a copy of the then recently published book From Underdogs to Tigers: The Rise and Growth of the Software Industry in Brazil, China, India, Ireland, and Israel [1] was obtained. This book offers more updated and broader information about software industries and could be used instead of the previous articles or in conjunction with them.

With the aim of introducing the topic of services versus products in the case of software, the article "Software Strategies in Developing Countries" from Heeks [15] was used. This classifies software industries in developing countries according to software strategy (services to develop customized software versus software packages) and market served (domestic versus international), allowing such industries to be classified into five quadrants as shown in figure 1.

\section{Software strategy}

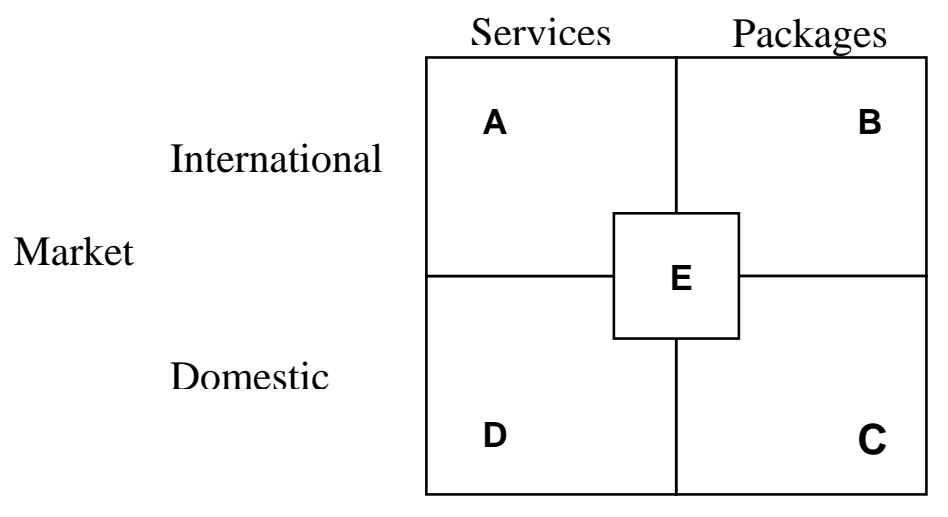

Figure 1. Strategic positioning of software industries in developing countries. Adapted from Heeks [15]. 
Along the theme of entrepreneurship and software development, it was considered important to compare and contrast proprietary software and free and open source software (FOSS), as well as to discuss the impact of national policies favoring FOSS in a country. To accomplish this purpose, the following bibliographical resources were used:

- Free, Open or Proprietary? [10];

- $\quad$ Boundaries of Open Source Software [19];

- $\quad$ Free and Open Source Software Approaches in Brazil and Argentina [21].

For the theme of entrepreneurship and IT-enabled services, the book Electronic Commerce: A Managerial Perspective $2004^{2}$ by Turban et al. [38] was used with the aim of introducing key concepts related to e-commerce, for example electronic markets, modalities of e-commerce (B2C versus B2B) and associated business models. Such topics were complemented by articles related to the fall of e-commerce in the 90s and its rise again in the new millennium:

- How E-Biz Rose, Fell, and will Rise Anew [17]: this article makes an interesting comparison between the technology bubble in the global stock markets in the 90s with the railroad bubble in the British market during the industrial revolution, explaining this phenomenon as a matter of lack of technological maturity.

- Strategy and the Internet [30]: paper written by Porter and published by Harvard Business Review which explains the technology bubble phenomenon as an effect of dot com business departing from traditional strategy.

- A Perfect Market: A Survey of E-Commerce [35]: this article from The Economist provides good examples of successful e-commerce applications.

Finally, the following topics were included within the theme of critical aspects for IT entrepreneurship in Costa Rica:

- $\quad$ IT and economic development;

- International marketing:

- National infrastructure;

- $\quad$ Funding possibilities and opportunities for IT businesses;

- Human resources;

- Legal framework.

Such topics were considered not only in the case of Costa Rica, but also of other countries. Bibliographic references for them were primarily selected from works undertaken as a result of two projects funded by the Inter-American Bank to promote the IT sector in Costa Rica: PROSOFTWARE and LINK (see section 4 for such references).

\section{Pedagogical aspects of the course}

A combination of pedagogical strategies was used for this course. These strategies included presentations by the professors, works and presentations by the students, and a round table with Costa Rican entrepreneurs.

Presentations by the professors were used to introduce and discuss the majority of the themes and topics selected for the course and described in the previous section. One notable exception to this was the topics related with critical aspects for IT entrepreneurship in Costa Rica, which were presented by the students after conducting research related to them. This allowed students to carry out applied research in topics of interest to this course and linked to national reality. In addition to their presentations, students were asked to submit a report about their research.

Students also had to carry out home work related to the themes of the course by providing answers to selected minicases from the book Essentials of Entrepreneurship and Small Business Management” [41], described in the previous section.

Finally, students had to develop, in groups of maximum two, a business plan for a hypothetical new IT business. The purpose of this business was defined by the students and approved by the professors. The proposed commercial venture had to be within any of the two IT sub-sectors studied in the course: software development or IT-enabled

\footnotetext{
${ }^{2}$ Currently there is a 2008 edition of this book.
} 
services. The methodology presented in the book by Zimmerer y Scarborough [41] was used to develop this plan. This methodology includes the following elements:

- Strategic aspects

o Vision and mission of the company

o Business profile and competition

o Business strategy

o Products and services

- Marketing aspects
o Target market
o Advertisement and promotion
o Pricing

- Administrative aspects

o Company organization

o Key management positions

- Operational aspects

0 Inventory management

o Distribution

o Other logistical considerations

- Financial aspects

o Pro-forma financial statements (balance sheet, income statement, and cash flow)

o Break-even point analysis

o Funding sources

A report with the business plan was submitted and a presentation made by the students at the end of the course.

Another important element of the course was a round table discussion with four well-known Costa Rican IT entrepreneurs. The objective of this activity was to present students concrete experiences about opportunities, as well as problems, in developing new IT ventures in Costa Rica.

In addition, the course included a take-home exam. In it, students had to demonstrate knowledge and skills related to the different themes and topics covered in this course.

\section{Objectives and program of the course}

Taking into account the previous considerations, the general objective of this course was:

To introduce students of the Graduate Program in Computer Science and Informatics of the Universidad de Costa Rica to relevant concepts about entrepreneurship and management of SMEs and relate these concepts to IT products and services.

Within this general objective, the scope of this course was limited to IT ventures related to software development and/or IT-enabled services, as already discussed.

The specific objectives of this course were:

- To understand the basic principles of entrepreneurship and their application to new IT businesses;

- To recognize opportunities and challenges in creating new IT companies related to software development and/or IT-enabled services;

- To identify critical factors for IT entrepreneurship relevant to the national environment;

- To develop an effective business plan for a new IT venture in Costa Rica.

The course was organized into five modules, around the themes already described, and divided into topics. These modules and their associated topics along with supporting references are presented below.

Module 1 Importance aspects for entrepreneurship

a. Foundations of entrepreneurship

References: Zimmerer and Scarborough (chapter 1) [41]

b. Role of the entrepreneur: Make ideas into reality

References: Zimmerer and Scarborough (chapter 2) [41] 
Module 2: Development of a plan for a new business

a. Strategic considerations

References: Zimmerer and Scarborough (chapter 3) [41] and Moore (chapters 1 and 2) [25]

b. Marketing considerations

References: Zimmerer and Scarborough (chapters 6, 7 and 8) [41]

c. Financial considerations

References: Zimmerer and Scarborough (chapters 9, 10 and 12) [41]

d. Administrative and operational considerations References: Zimmerer and Scarborough (chapter 15) [41]

e. Writing an effective business plan References: Zimmerer and Scarborough (chapter 11) [41], Rich and Gumpert (chapter 1) [31], and Sahlman [32]

Module 3: Entrepreneurship and software development

a. Characteristics of the software industry at the global level and in selected countries

References: Arora and Gambardella [1] (included after the course) and Heeks and Nicholson [16]

b. Products versus services References: Heeks [15], Friedman [13], and Business Week [6]

c. Free and Open Source Software versus proprietary software References: Kuan [19], Mannila [21], and Chance [10]

d. Example of software industries around the world References: Arora and Gambardella (chapters 2, 3, 4, 5 and 6) [1] (included after the course), Arora et al. [2], Athreye [3], Singh [34], Tschang [37] and Baeza-Yates et al. [5]

e. Opportunities and challenges in software development ventures in Costa Rica References: Vargas et al. (chapters 2, 5 and 6) [39] and Cámara de Tecnologías de Información y Comunicación et al. [7]

Module 4: Entrepreneurship and IT-enabled services

a. Commercial importance of Internet References: Turban et. al (chapters 1, 3 and 6) [38]

b. Rise, fall and consolidation of dot com companies References: Hof y Hamm [17], Porter [30], and The Economist [35, 36]

c. Examples of IT-enabled industries and companies References: Articles on Internet about Amazon, Dell, E-Bay, Google, MercadoLibre, PayPal, Skype, and Yahoo

d. Opportunities and challenges for IT-enabled ventures in Costa Rica

Module 5: Critical aspects of IT entrepreneurship in Costa Rica

a. Economic development

References: Clarke [11], OECD [29], Sallstrom and Damuth [33], and Larrain et al. [20]

b. International marketing References: Carmel [8, 9]

c. Infrastructure

d. Funding References: Nicholson and Sahay (chapters 2 and 5) [28]

References: Interbolsa [18], Mora \& Beck Asociados [26], and Nicholson and Sahay (chapter 5) [28]

e. Human resources

References: Mata et al. [22, 23], Mata and Jofré [24], and Nicholson and Sahay [27]

f. Legal framework

References: Sallstrom and Damuth [33] and websites about digital signature in Costa Rica:

http://www.micit.go.cr/docs/Ley\%20de\%20firma\%20digital.doc,

http://www.micit.go.cr/docs/Reglamento\%20Firma\%20versión\%2029-03-2006

\section{Course schedule and evaluation for the students}

This course was taught in a sixteen-week period with a four-hour class per week. The distribution of modules and activities for each week is shown in table 1. 


\begin{tabular}{|c|c|c|c|c|c|c|c|c|c|c|c|c|c|c|c|c|}
\hline \multirow{2}{*}{ Module or activity } & \multicolumn{16}{|c|}{ Week } \\
\hline & 1 & 2 & 3 & 4 & 5 & 6 & 7 & 8 & 9 & 10 & 11 & 12 & 13 & 14 & 15 & 16 \\
\hline \multicolumn{17}{|l|}{ Introduction to the course } \\
\hline \multicolumn{17}{|l|}{ Module 1} \\
\hline \multicolumn{17}{|l|}{ Module 2} \\
\hline \multicolumn{17}{|l|}{ Module 3} \\
\hline \multicolumn{17}{|l|}{ Module 4} \\
\hline \multicolumn{17}{|l|}{$\begin{array}{l}\text { Module } 5 \\
\text { (Presentations by students of } \\
\text { research on critical aspects for } \\
\text { IT entrepreneurship in Costa } \\
\text { Rica) }\end{array}$} \\
\hline \multicolumn{17}{|l|}{$\begin{array}{l}\text { Round table with IT } \\
\text { entrepreneurs }\end{array}$} \\
\hline \multicolumn{17}{|l|}{$\begin{array}{l}\text { Presentation of business } \\
\text { plans }\end{array}$} \\
\hline Final exam & & & & & & & & & & & & & & & & \\
\hline
\end{tabular}

Table 1. Course schedule.

The evaluation for the students was based on the following criteria:

$\begin{array}{cc}\text { Research on critical aspects for IT entrepreneurship in Costa Rica } \\ \text { Proposal } & 5 \% \\ \text { Progress report } & 5 \% \\ \text { Final report } & 10 \% \\ \text { Presentation in class } & 5 \%\end{array}$

Business plan

$\begin{array}{lr}\text { Proposal } & 5 \% \\ \text { Progress report } & 5 \% \\ \text { Final report } & 20 \% \\ \text { Presentation in class } & 10 \%\end{array}$

Final exam

\section{Course assessment and recommendations}

Although this course has been offered once, due to time limitations of the two professors to teach it again, the assessment by the students for the first offering was very encouraging. In this regard, the students found the themes and topics presented very useful and its teaching methodology very appropriate. A great part of this success can be explained by the participation of two professors in the course with complementary expertise: one with large academic experience in the fields of computer science and management information systems and another with proven experience in entrepreneurship, having created several IT companies in Costa Rica including one of the major players in the Costa Rican software industry.

From a teaching perspective, it is important to highlight the novelty of the themes and topics for most of the students registered in this course. This was due to the fact that students in computer science have little knowledge about business administration. Besides some computer science students, particularly those pursuing a more technologicaloriented career, do not have any interest in topics related to this later field. To ameliorate these problems, a fairly detailed presentation about the objectives and scope of the course was made at the beginning of the course. Also, it was very helpful to use a textbook which explains in a simple and easy manner entrepreneurship terms and concepts related to business administration, as it is the case with the book by Zimmerer and Scarborough [41].

Although during the design of the course, the professors thought that the development of a business plan could be problematic for the students, during the course, it was possible to realize how the students were able to conduct this task easily and with great interest once they understood the concepts involved and the terminology used. In spite of 
this fact, the sections of the plan about marketing, particularly related to identifying a target market, and finance, mainly related to income estimations, were the more difficult for the students. This situation was not surprising since those particular sections are the ones requiring more information and experience in any business plan.

Based on the offering of this course in the year 2006, the following recommendations are made to enhance it:

- Promote a greater participation of the students in the course. This could be achieved by reducing the number of themes/topics with the aim of leaving more time in class for discussions and student participation.

- Present cases of IT entrepreneurships and ventures. Students could collaborate in this endeavor and a library of such cases could be created in a website associated to this course.

- Include more presentations about Costa Rican IT entrepreneurs. Although the round table with entrepreneurs at the end of the course allowed students to obtain first-hand experience on IT entrepreneurship in Costa Rica, more presentations on this matter would be useful to motivate students and elaborate further on concrete examples.

- Present a better description of the IT sector in Costa Rica with the aim of identifying its own characteristics and compare and contrast them with those of other countries. Even though there is information available on this topic, a good description of the IT sector in Costa Rica would require considerable effort in order to carry out a synthesis from different sources as well as to obtain new or updated information.

\section{References}

[1] Arora, A. and Gambardella, A. (eds.). From Underdogs to Tigers: The Rise and Growth of the Software Industry in Brazil, China, India, Ireland, and Israel. Oxford University Press. 2005.

[2] Arora, A., Gambardella, A. and Torrisi, S. In the footsteps of the Silicon Valley: Indian and Irish Software in the International Division of Labor. Report 02-01, Software Industry Center, Carnegie Mellon University. 2002. [http://www.softwarecenter.cmu.edu/CenterPapers/Indian_Irish_Soft.pdf].

[3] Athreye, S.S. The Indian Software Industry. Report 03-04, Software Industry Center, Carnegie Mellon University. 2003. [http://www.softwarecenter.cmu.edu/CenterPapers/Indian_Software.pdf].

[5] Baeza-Yates, R.A., Fuller, D.A., Pino, J.A. and Goodman, S.E. Computing in Chile: The Jaguar of the Pacific Rim? Communications of the ACM. Vol 38, No 9 (September 1995), pp. 23-28.

[6] Business Week. Can Latin America Challenge India? 30 January 2006. [http://www.businessweek.com/ magazine/content/06_05/b3969427.htm].

[7] Cámara de Tecnologías de Información, Banco Central de Costa Rica, Instituto Centroamericano de Administración de Empresas. Estado Nacional de Software 2005: Estadísticas Sectoriales de Costa Rica. Presentation. 2005.

[http://www.camtic.org/ES/phtml/descargarDoc.phtml?arc=Estado_Nacional_Sector_Software_2005.ppt|72.pb. arc.338.ppt].

[8] Carmel, E. The New Software Exporting Nations: Impacts on National Well Being Resulting From Their Software Exporting Industries. Electronic Journal on Information Systems in Developing Countries. Vol 13, No 3 (2003), pp. 1-6. [http://www.is.cityu.edu.hk/research/ejisdc/vol13/v13r3.pdf].

[9] Carmel, E. Taxonomy of Software Exporting Nations. Electronic Journal on Information Systems in Developing Countries. Vol 13, No 2 (2003), pp. 1-6. [http://www.is.cityu.edu.hk/research/ejisdc/vol13/v13r2.pdf].

[10] Chance, T. Free, Open or Proprietary? Free Software Magazine. No 9 (November-December 2005). [http://www.freesoftwaremagazine.com/articles/philosophical_diff_fs].

[11] Clarke, M. e-Development? Development and the New Economy. Policy Brief No. 7, World Institute for Development Economics Research, University of the United Nations. 2003 . [http://www.wider.unu.edu/ publications/pb7.pdf].

[12] Cordero Pérez, C. Diecisiete firmas encabezan sector informático. El Financiero. No. 599 (15-21 January 2007), pp. 10-11. [http://www.elfinancierocr.com/ef_archivo/2007/enero/21/informe954237.html]. 
[13] Friedman, T.L. It's a Flat World, After All. The New York Times. 3 April 2005. [http://www.nytimes.com/2005/04/03/magazine/03DOMINANCE.html?ei=5090\&en=cc2a003cd936d374\&ex= 1270267200].

[14] Friedman, T.L. The World is Flat: A Brief History of the Twenty-First Century. Farrar Straus \& Giroux. 2006.

[15] Heeks, R. Software Strategies in Developing Countries. Communications of the ACM. Vol 42, No 6 (June 1999), pp. 15-20 (also available as Report 6/1999, Institute for Development Policy and Management, University of Manchester. 1999 [http://www.sed.manchester.ac.uk/idpm/research/publications/wp/di/ di_wp06.htm]).

[16] Heeks, R. and Nicholson, B. Software Export Success Factors and Strategies in Developing and Transitional Economies. Report 12/2002, Institute for Development Policy and Management, University of Manchester. 2002. [http://www.sed.manchester.ac.uk/idpm/publications/wp/di/di_wp12.pdf].

[17] Hof, R.D. and S. Hamm. How E-Biz Rose, Fell, and will Rise Anew. Business Week. 13 May 2002, pp. 64-72. [http://www.businessweek.com/magazine/content/02_19/b3782601.htm].

[18] Interbolsa. Alternativas de Financiamiento para Empresas de Software. PROSOFTWARE-Cámara de Productores de Software. 2001. [http://www.camtic.org/ES/phtml/descargarDoc.phtml? arc=EI_001.pdf|46.pb.arc.240.pdf].

[19] Kuan, J. Boundaries of Open Source Software. Technical report, Carnegie Mellon University-Stanford University. 2005.

[20] Larrain B., F., Lopez-Calva, L.F. and Rodríguez.Clare, A. Intel: A Case Study of Foreign Direct Investment in Central America. CID Working Paper No. 58, Center for International Development, Harvard University. 2000. [http://www.ksg.harvard.edu/CID/cidwp/058.pdf].

[21] Mannila, M. Free and Open Source Software Approaches in Brazil and Argentina. Working paper 5, University of Tampere, Finland. 2005. [http://www.uta.fi/hyper/julkaisut/b/mannila-2005.pdf].

[22] Mata, F.J., Matarrita, R., and Araya, E. Hacia una Estrategia para el Fortalecimiento del Capital Humano para la Industria de Desarrollo de Software: Conclusiones y Recomendaciones del Estudio para el Fortalecimiento de los Centros de Enseñanza y la Actualización Curricular. PROSOFTWARE-Cámara de Productores de Software. 2003.

[23] Mata, F.J., Matarrita, R. and Araya, E. Idoneidad del Recurso Humano para la Industria de Desarrollo de Software de Costa Rica: Metodología y Resultados del Estudio para el Fortalecimiento de los Centros de Enseñanza y la Actualización Curricular. XII Jornadas Chilenas de Computación. 2004.

[24] Mata, F.J. and Jofré, A. Informe Final Estudio de Oferta y Demanda del Recurso Humano. PROSOFTWARECámara de Productores de Software. 2001. [http://www.camtic.org/ES/phtml/descargarDoc.phtml? arc=EE_002.pdf|47.pb.arc.241.pdf]

[25] Moore; G.A. Crossing the Chasm. Harper Business. 1991.

[26] Mora \& Beck Asociados. Diseño y Creación de un Fondo de Capital de Riesgo para la Industria de Software de Costa Rica. Fase I: Benchmarking [http://www.camtic.org/ES/phtml/descargarDoc.phtml?arc=EI_003.pdf|48.pb.arc.242.pdf] and Fase II: Investigación de campo [http://www.camtic.org/ ES/phtml/descargarDoc.phtml? arc=EI_004.pdf|49.pb.arc.243.pdf]. PROSOFTWARE-Cámara de Productores de Software. 2002

[27] Nicholson, B. and Sahay, S. Human Resource Development Policy in the Context of Software Exports: Case Evidence from Costa Rica. Report 23/2005, Institute for Development Policy and Management, University of Manchester. 2005. [http://www.sed.manchester.ac.uk/idpm/publications/wp/di/di_wp23.pdf].

[28] Nicholson, B. and Sahay, S. Strategic Plan to Develop the Costa Rican Software Industry. PROSOFTWARECámara de Productores de Software. 2003.

[29] OECD. ICT and Economic Growth. Organisation for Economic Co-operation and Development. 2003. 
[30] Porter, M. Strategy and the Internet. Harvard Business Review. March 2001, pp. 63-78.

[31] Rich, S.R. and Gumpert, D.E. Business Plans that Win \$\$. Harper \& Row. 1985.

[32] Sahlman, W. How to Write a Great Business Plan. Harvard Business Review. July-August 1997, pp. 98-107.

[33] Sallstrom. L., Damuth, R. El Papel Fundamental de la Industria de Software en el Crecimiento Económico, Foco: Costa Rica. Cámara de Productores de Software-CompTIA. 2004.

[34] Singh, N. India's Information Technology Sector: What Contribution to Broader Economic Sector. Technical report No. 207, Organisation for Economic Co-operation and Development. 2003. [http://www.oecd.org/dataoecd/59/12/2503442.pdf].

[35] The Economist. A Perfect Market: A Survey of E-Commerce. 15 May 2004, pp. 3-16.

[36] The Economist. E-Commerce Takes Off. 15 May 2004, p. 9.

[37] Tschang, T. China's Software Industry and its Implications for India. Technical Report 205, Organisation for Economic Co-operation and Development. 2003. [http://www.oecd.org/dataoecd/14/18/2497604.pdf].

[38] Turban, E., King, D., Lee, J. and Viehland, D. Electronic Commerce: A Managerial Perspective 2004. Pearson Education International. 2004.

[39] Vargas Alfaro, L., Arce Alvarado, R., Miranda Montes, D., Barquero Alpízar, O., Millar, K. and Trigueros Varela, J. La Industria de Software en Costa Rica: Bases para la Definición de un Plan Estratégico Nacional. Centro Internacional de Política Económica para el Desarrollo Sostenible, Universidad Nacional. 2003.

[40] Wikipedia article on Crossing the Chasm [http://en.wikipedia.org/wiki/Crossing_the_chasm]

[41] Zimmerer, T.W., and Scarborough, N.M. Essentials of Entrepreneurship and Small Business Management. 4 ed. Prentice Hall. 2005. 